\title{
Enhanced long-term organics and nitrogen removal and associated microbial community in intermittently aerated subsurface flow constructed wetlands
}

Jinlin Fan ${ }^{a, 1}$, Jian Zhang ${ }^{b, 1}$, Wenshan Guo ${ }^{c}$, Shuang Liang ${ }^{c}$, Haiming $W u^{d *}$

${ }^{a}$ National Engineering Laboratory of Coal-Fired Pollutants Emission Reduction, Shandong University, Jinan 250061, PR China

${ }^{b}$ School of Environmental Science \& Engineering, Shandong University, Jinan 250100, PR China

${ }^{c}$ School of Civil and Environmental Engineering, University of Technology Sydney, Broadway, NSW 2007, Australia

${ }^{d}$ College of Resources and Environment, Northwest A \& F University, Yangling, Shaanxi 712100, China

\section{Abstract}

The long-term enhanced removal efficiency of organics and nitrogen in subsurface flow constructed wetlands (SSF CWs) with and without intermittent aeration for decentralized domestic wastewater was evaluated, and the function of intermittent aeration on microbial community was also investigated in this study. The high and long-term 95.6\% COD, 96.1\% $\mathrm{NH}_{4}{ }^{+}-\mathrm{N}$ and $85.8 \% \mathrm{TN}$ removal efficiencies were achieved in experimental intermittently aerated SSF CW compared with non-aerated SSF CW. Aerated SSF CWs also exhibited the excellent removal performance when comparatively comparing with other strategies and techniques applied in CWs. In addition, fluorescence in situ hybridization (FISH) analysis revealed that associated microbial abundance significantly increased owing to intermittent aeration. These results indicated intermittent aeration CWs might be an effective and sustainable

${ }^{1}$ These authors contributed equally to this work.

"Corresponding author. Email address: haimingwu14@nwsuaf.edu.cn (Haiming Wu) 
strategy for wastewater treatment in rural areas, but require further full-scale investigation in future.

Keywords: Vertical flow constructed wetlands; Intermittent aeration; Denitrification; Nitrification; Nitrogen removal

\section{Introduction}

Excessive discharge of nitrogen, phosphorus and organics to water bodies can cause serious ecological and environmental problems worldwide (Li et al., 2014). Compared to conventional biological treatment technologies, Subsurface flow constructed wetlands (SSF CWs) are a promising approach to treat different wastewaters due to lower operation costs and energy consumption (Wu et al., 2015a). In such green and sustainable systems, various pollutants (organics, nutrients, heavy metals, etc.) can be removed through a variety of physical and biochemical mechanisms, however nitrogen removal is usually far from satisfactory when facing the growing environmental legislation and increasingly more stringent emission standards for pollutants (Wu et al., 2015b). It is noted that either nitrification by nitrifying bacteria or denitrification process by heterotrophic denitrifying bacteria causes low nitrogen removal efficiency in CWs, and can also be influenced by many environmental and operating parameters (Saeed and Sun, 2012). Especially in SSF CWs, the nitrification process is recognized as the first limiting step for nitrogen removal, and available dissolved oxygen is the key in nitrogen transformation because of nitrifying bacteria competing with organics for limited DO (Fan et al., 2013).

Considering to increase oxygen availability in CWs, artificial aeration (mainly continuous aeration and intermittent aeration) have been proven to be an alternative to provided sufficient oxygen, which can facilitate effective nitrification and thus 
subsequently guarantee denitrification for complete total nitrogen (TN) elimination (Foladori et al., 2013; Li et al., 2014). Artificial CWs are just installed air distribution lines at the base of the system to increase the oxygen transfer rate, and a plenty of investigations on artificial CWs indicated that it has higher TN removal performance than traditional CWs without artificial aeration (Nivala et al., 2007; Wu et al., 2016). In addition, several studies reported that intermittent aeration in CWs would be preferable to the continuous mode due to providing proper spatial aerobic and anoxic conditions for the simultaneous nitrification and denitrification (Wu et al., 2015c; Uggetti et al., 2016; Murphy et al., 2016). Those studies achieving effective and high TN removal were mainly depending on short-term laboratory aeration CWs (Wang et al., 2015), but very few literatures focus on the long-term evaluation of application of intermittent aeration in SSF CWs. Therefore, detailed knowledge about the intermittent aeration on enhancing long-term removal efficiency of pollutant in SSF CWs would be required in particular for its successful application in decentralized domestic wastewater treatment in rural areas.

The aim of this work was to quantify the long-term enhanced removal efficiency of organics and nitrogen in intermittently aerated SSF CWs for decentralized domestic wastewater. Treatment performance was further comparatively compared with other strategies and techniques used in CWs. The influence of intermittent aeration on microbial community was also investigated by FISH.

\section{Material and Methods}

\subsection{Study site and experimental system}

The experiment was performed under the transparent rain shelter in Baihua Park in Jinan, northern China $\left(36^{\circ} 40^{\prime} 36^{\prime \prime} \mathrm{N}, 117^{\circ} 03^{\prime} 42^{\prime \prime} \mathrm{E}\right)$. The experimental systems 
consisted of two parallel laboratory-scale SSF CWs designed in a vertical-flow (VF) style (System I: intermittent aeration CW; System II: Non-aerated CW) were developed (as shown in Fig. S1). All the CW systems were $65 \mathrm{~cm}$ in height and $20 \mathrm{~cm}$ in diameter, and multi-dimensional gradation of the substrate (gravel and sand) and porous air spargers were used for oxygen supply and oxygen diffusion as described in detail by Fan et al. (2013). Average void volume of each CW system was $6.5 \mathrm{~L}$ (porosity $=0.35$ ) and was planted with Phragmites australis (approximately $20 \mathrm{~cm}$ in height) at a density of eight rhizomes per system. After transplanting, VF CW microcosms were fed with secondary effluent for one month until wetland plants and microorganisms were well established, and then the experiment started.

\subsection{System operation}

After an acclimation period, the systems were fed with synthetic wastewater to start the experiment. The details of synthetic wastewater and the characteristics of the influents have been given in a previous paper (Wu et al., 2016). All microcosms were operated in a sequencing fill-and-draw batch mode with the hydraulic retention time (HRT) of $72 \mathrm{~h}$, one of which was intermittently aerated with an airflow rate of $1.0 \mathrm{~L}$ $\min ^{-1}$ for $4 \mathrm{~h}$ (hours $0-1,6-7,12-13$ and 18-19) each day. At the start of each cycle, wastewater was supplied into each system at the flow rate of $0.21 \mathrm{~m}^{3} \mathrm{~m}^{-2}$-batch ${ }^{-1}$. Effluent was manually drained through a valve at the bottom of each wetland after a cycle, and then re-filled with the wastewater immediately after drainage. The experimental CW systems were operated for a period of 220 days.

\subsection{Sampling and analysis}

\subsubsection{Water sampling and analysis}

Water samples of influent and effluent were taken to analyze the transformation of 
organics and nitrogen in all systems every $3 \mathrm{~d}$, respectively. According to standard methods (APHA, 2005), all samples were transferred immediately to the lab and analyzed immediately for chemical oxygen demand (COD; HACH DR $2008^{\text {TM }}$ Spectrophotometer, USA), ammonia nitrogen $\left(\mathrm{NH}_{4}{ }^{+}-\mathrm{N}\right)$ and TN. Dissolved oxygen (DO) was measured in situ by a DO meter (HQ 30d 53LED ${ }^{\mathrm{TM}} \mathrm{HACH}$, USA) and a glass $\mathrm{pH}$ meter (SG2-T SevenGo pro ${ }^{\mathrm{TM}}$ MTD, Switzerland).

\subsubsection{Microbial sampling and analysis}

FISH was employed to investigate microbial community composition in CW systems. At the end of the experiment, microbial samples were collected from the wetland microcosms by mixing the substrate in the middle section and the interstitial water in the saturated zone. Then all samples were transported to the laboratory immediately and stored at $4^{\circ} \mathrm{C}$. The details of preparing samples and steps of hybridization were according to the method described in the previous studies (Fan et al., 2013). The dominant bacteria, ammonia-oxidizing b-Proteobacteria, Nitrospira and Nitrobacter were characterized using the group-specific 16S rRNA gene probes: EUB $B_{\text {mix }}$ (EUB 338, EUB 338-II and EUB 338-III) labeled with FITC, Nso 1225 labeled with Cy3, and Nstpa 662 and Nit 3 labeled with Cy3, respectively (Table S1). FISH micrographs were captured digitally with an optical fluorescence microscope (BX53, Olympus Co., Ltd., Japan), and digital images were analyzed using Image-Pro Plus 6.0 software (Media Cybernetics, Inc., Bethesda, MD).

\subsection{Statistical analysis}

Statistical analyses were performed applying the software SPSS 11.0 (SPSS Inc., Chicago, USA). Two-sample t-tests were used to evaluate the significance of differences between means. In all tests, differences and correlations were considered 
statistically significant when $\mathrm{P}<0.05$.

\section{Results and Discussion}

\subsection{Overall performance of organic matter and nitrogen removal}

\subsubsection{COD removal}

The aerobic heterotrophic bacteria played an important role in the aerobic degradation of organic matters (Saeed and Sun, 2012). As shown in Table S2, DO concentration in the intermittent aerated system (DO $5.62 \mathrm{mg} \mathrm{L}^{-1}$ ) was enhanced significantly owing to oxygen supply via intermittent aeration, however, DO concentration in the non-aerated CW was only $0.39 \mathrm{mg} \mathrm{L}^{-1}$ which caused an anaerobic environment in CWs. The influent and effluent water quality of the experimental SSF CWs without aeration and with intermittent aeration is shown in Fig. 1. In intermittent aerated CW, organic matters degradation removal efficiency was much higher than that of non-aerated CW. The effluent COD concentration in intermittent aerated system was below $50 \mathrm{mg} \mathrm{L}^{-1}$ during the experimental period, which can comply with the Class I $(A)$ of Wastewater Discharge Standard (GB18918-2002) in China. However, in non-aerated system, the effluent COD concentration ranged between $56 \mathrm{mg} \mathrm{L}^{-1}$ and $128 \mathrm{mg} \mathrm{L}^{-1}$, moreover, significant increase of COD concentration was observed due to declining air temperature and withered plants at the end of the experiment. Ong et al. (2010) reported that additional oxygen supply could greatly enhance the performance of aerobic biochemical oxidation and improved the COD removal rate. On the whole, the overall COD removal efficiency was $95.6 \%$ in intermittent aerated system (Table S2), while the lower COD removal efficiency (77.6\%) was obtained. In addition, average COD removal efficiency obtained in this study was higher than other kinds of enhancing CW systems (Table 1), such as continuous aeration (90-94\%, Ong et al., 2010), tidal flow operation (82\%, Sun et al., 2006), effluent recirculation (84\%, 
Foladori et al., 2013), bioaugmentation (65\%, Zhao et al., 2016), electrolysis-tidal CW (85\%, Ju et al., 2014), biological reactor-VF CW (82\%, Bilgin et al., 2014), but lower than other studies, such as microbial fuel cell -VF CW (100\%, Oon et al., 2015).

\subsection{2 $\mathrm{NH}_{4}{ }^{+}-\mathrm{N}$ removal}

When concerning $\mathrm{NH}_{4}{ }^{+}-\mathrm{N}$ removal, the effluent $\mathrm{NH}_{4}{ }^{+}-\mathrm{N}$ concentration in intermittent aerated system was $11-13 \mathrm{mg} \mathrm{L}^{-1}$ in the beginning because of immature plants and microorganisms, and then decreased to below $5 \mathrm{mg} \mathrm{L}^{-1}$, which can comply with the Class I (A) of Wastewater Discharge Standard (GB18918-2002) in China. By contrast, the non-aerated system had a lower removal efficiency of $31.1 \%$ (Table S2), with the effluent $\mathrm{NH}_{4}{ }^{+}-\mathrm{N}$ concentration ranging between $23 \mathrm{mg} \mathrm{L}^{-1}$ and $34 \mathrm{mg} \mathrm{L}^{-1}$ (Fig. 1). This result indicated that intermittent aeration had an important effect on the removal of $\mathrm{NH}_{4}{ }^{+}-\mathrm{N}$, which is in agreement with previous reports (Fan et al., 2013; Wu et al., 2015b). On the whole, the average $\mathrm{NH}_{4}{ }^{+}-\mathrm{N}$ removal efficiency in intermittent aerated system recorded in this study (96.1\%) was similar to the result $59-98 \%$ of continuous aeration (Ong et al., 2010) and 100\% of microbial fuel cell-VF CW (Oon et al., 2015), but higher than other studies, such as $58 \%$ of tidal flow operation (Sun et al., 2006), 73\% effluent recirculation (Foladori et al., 2013), 84\% bioaugmentation (Zhao et al., 2016) and $80 \%$ electrolysis-tidal CW (Ju et al., 2014). These results indicated that intermittent aeration was an effective strategy for SSF CWs to enhance $\mathrm{NH}_{4}{ }^{+}-\mathrm{N}$ removal.

\subsubsection{TN removal}

As shown in Fig. 1, the effluent TN concentration in intermittent aeration system varied greatly from $0.7 \mathrm{mg} \mathrm{L}^{-1}$ to $19.2 \mathrm{mg} \mathrm{L}^{-1}$ throughout the experimental period, and on the average, the effluent TN concentration was $6.3 \mathrm{mg} \mathrm{L}^{-1}$ which can also comply 
with the Chinese Class I (A) of Wastewater Discharge Standard (GB18918-2002). However, at the beginning of the experimental period, a low TN removal was achieved, which was due to weak growth of plant and microorganisms. In the later period of the experiment, the effluent concentration of $\mathrm{TN}$ increased rapidly because the declining air temperature inhibited the microbial activity and the plants started to decay and died off. On the whole, the average TN removal efficiency was $85.8 \%$ in intermittent aerated system (Table S2), significantly higher than that (30.7\%) obtained in the non-aerated CW. This result also indicated that intermittent aeration could greatly increase TN removal efficiency by creating favourable conditions for nitrification and denitrification simultaneously (Foladori et al., 2013; Fan et al., 2013). In addition, our results show a substantial improvement for the TN removal compared to other enhancing CWs reported in previous studies, such as effluent recirculation (72\%) by Foladori et al. (2013), bioaugmentation (74\%) by Zhao et al. (2016) and biological reactor-VF CW (59\%) by Bilgin et al. (2014), and similar to the result obtained in continuous aeration CWs (69-92\%) by Ong et al. (2010). These findings illustrated that SSF CWs using intermittent aeration might be a potential choice to intensify nitrogen removal performance sustainably for the decentralized domestic wastewater treatment.

\subsection{Microbial community}

FISH analysis was used to detect the influence of intermittent aeration on microbial community in SSF CWs during the long-term operation period. As shown in Fig. 2, based on FISH analysis, remarkable difference in microbial community was found in SSF CWs with and without intermittent aeration. More negligible nitrifying bacteria ( $\mathrm{AOB}$ and $\mathrm{NOB}$ ) and other viable bacteria were detected in intermittent aeration system, and the relative abundance of $\mathrm{AOB}$ and NOB in the aerated CW were $45.3 \%$ 
and $35.6 \%$. On the contrary, $\mathrm{AOB}$ and NOB merely accounted for $5.8 \%$ and $7.6 \%$ of the total bacteria in the non-aerated CW. Apparently, intermittent aeration in the wetlands supplying sufficient oxygen diffusion was beneficial to promote growth and reproduction of $\mathrm{AOB}$ and $\mathrm{NOB}$, and in turn more efficient to keep high removal efficiency (Saeed and Sun, 2012). Besides, FISH results demonstrated the function of intermittent aeration on enhancing long-term $\mathrm{NH}_{4}{ }^{+}-\mathrm{N}$ and $\mathrm{TN}$ removal efficiency involved in the present study. This was consistent with the findings of Li et al. (2014) and Fan et al. (2013) that the microbial community was stimulated by favorable aerobic conditions owing to additional oxygen supply.

\section{Conclusions}

The application of intermittent aeration in SSF CWs significantly enhanced the removal performance in synthetic decentralized domestic wastewater treatment, and high and long-term organic matter and nitrogen removal performance was achieved in experimental SSF CWs with intermittent aeration. Average removal efficiencies of COD, $\mathrm{NH}_{4}{ }^{+}-\mathrm{N}$ and $\mathrm{TN}$ were $95.6 \%, 96.1 \%$ and $85.8 \%$, respectively. Furthermore, intermittent aeration significantly increased the abundance of nitrifying bacteria (AOB and NOB). Intermittent aeration SSF CWs might be an effective and sustainable strategy for wastewater treatment in rural areas.

\section{Acknowledgements}

We gratefully acknowledge financial support by the National Science Foundation of China (NSFC, Project No. 51508466, 51578321, 21507072), National Key Technology R\&D Program for the Twelfth Five-year Plan (No. 2015BAD22B02), and Shandong Provincial Natural Science Foundation (ZR2015PB001). 


\section{References}

1. APHA, 2005. Standard methods for the examinations of water and wastewater, 21st ed. APHA and AWWA and WEF DC, Washington.

2. Bilgin, M., Simsek, I., Tulun, S., 2014. Treatment of domestic wastewater using a lab-scale activated sludge/vertical flow subsurface constructed wetlands by using Cyperus alternifolius. Ecol. Eng. 70, 362-365.

3. Fan, J.L., Zhang, B., Zhang, J., Ngo, H.H., Guo, W.S., Liu, F.F., Guo, Y.Y., Wu, H.M., 2013. Intermittent aeration strategy to enhance organics and nitrogen removal in subsurface flow constructed wetlands. Bioresour. Technol. 141, $117-122$

4. Foladori, P., Ruaben, J., Ortigara, A.R., 2013. Recirculation or artificial aeration in vertical flow constructed wetlands: a comparative study for treating high load wastewater. Bioresour. Technol. 149, 398-405.

5. Ju X, Wu S, Huang X, Zhang Y, Dong R. 2014. How the novel integration of electrolysis in tidal flow constructed wetlands intensifies nutrient removal and odor control. Bioresour. Technol. 169, 605-613.

6. Li, F., Lu, L., Zheng, X., Ngo, H.H., Liang, S., Guo, W., Zhang, X., 2014. Enhanced nitrogen removal in constructed wetlands: effects of dissolved oxygen and step-feeding. Bioresour. Technol. 169, 395-402.

7. Murphy, C., Rajabzadeh, A.R., Weber, K.P., Nivala, J., Wallace, S.D., Cooper, D.J., 2016. Nitrification cessation and recovery in an aerated saturated vertical subsurface flow treatment wetland: Field studies and microscale biofilm modeling. Bioresour Technol. 209:125-132.

8. Nivala, J., Hoos, M.B., Cross, C., Wallace, S., Parkin, G., 2007. Treatment of landfill leachate using an aerated, horizontal subsurface-flow constructed wetland. 
Sci Total Environ. 380:19-27.

9. Ong SA, Uchiyama K, Inadama D, Ishida Y, Yamagiwa K. 2010. Performance evaluation of laboratory scale up-flow constructed wetlands with different designs and emergent plants. Bioresour. Technol. 101, 7239-7244.

10. Oon, Y.L., Ong, S.A., Ho, L.N., Wong, Y,S., Oon, Y.S., Lehl, H.K., Thung, W.E., 2015. Hybrid system up-flow constructed wetland integrated with microbial fuel cell for simultaneous wastewater treatment and electricity generation. Bioresour. Technol. 186, 270-275.

11. Sun, G., Zhao, Y., Allen, S., Cooper D., 2006. Generating "Tide" in pilot-scale constructed wetlands to enhance agricultural wastewater treatment. Eng. Life Sci. $6,560-565$.

12. Saeed, T., Sun, G., 2012. A review on nitrogen and organics removal mechanisms in subsurface flow constructed wetlands: dependency on environmental parameters, operating conditions and supporting media. J. Environ. Manage. 112, $429-48$.

13. Uggetti, E., Hughes-Riley, T., Morris, R.H., Newton, M.I., Trabi, C.L., Hawes, P., Puigagut, J., García, J., 2016. Intermittent aeration to improve wastewater treatment efficiency in pilot-scale constructed wetland. Sci Total Environ. 559:212-217.

14. Wang, X., Tian, Y., Zhao, X., Peng, S., Wu, Q., Yan, L., 2015. Effects of aeration position on organics, nitrogen and phosphorus removal in combined oxidation pond-constructed wetland systems. Bioresour Technol. 198:7-15.

15. Wu, H., Zhang, J., Ngo H.H., Guo W., Hu Z., Liang S., Fan J., Liu H., 2015a. A review on the sustainability of constructed wetlands for wastewater treatment: Design and operation, Bioresour. Technol. 175, 594-601. 
16. Wu H., Fan J., Zhang J., Ngo H.H., Guo W., Hu Z., Liang S. 2015b. Decentralized domestic wastewater treatment using intermittently aerated vertical flow constructed wetlands: impact of influent strengths. Bioresour. Technol. 176, 163-168.

17. Wu, H., Fan, J., Zhang, J., Ngo, H., Guo, W., Liang, S., Hu, Z., Liu, H., 2015c. Strategies and techniques to enhance constructed wetland performance for sustainable wastewater treatment, Environ. Sci. Pollut. R. 22, 14637-14650.

18. Wu, H., Fan, J., Zhang, J., Ngo, H., Guo, W., Liang, S., Lv, J., Hu, Z., Lu, S., Wu, W., Wu, S., 2016. Intensified organics and nitrogen removal in the intermittent aerated constructed wetland using a novel sludge-ceramsite as substrate, Bioresource. Technology, 210, 101-107.

19. Zhao, X., Yang, J., Bai, S., Ma, F., Wang, L., 2016. Microbial population dynamics in response to bioaugmentation in a constructed wetland system under $10^{\circ} \mathrm{C}$. Bioresour. Technol. 205:166-173. 


\section{Figure Captions:}

Figure 1 The influent and effluent water quality of the experimental SSF CWs without aeration and with intermittent aeration during 220 days of operation: (a) COD; (b) $\mathrm{NH}_{4}{ }^{+}-\mathrm{N}$ and (c) TN.

Figure 2 Relative abundance of $\mathrm{AOB}$ and $\mathrm{NOB}$ in SSF CWs (A: without aeration, $\mathrm{B}$ : intermittent aeration) based on FISH analysis. 


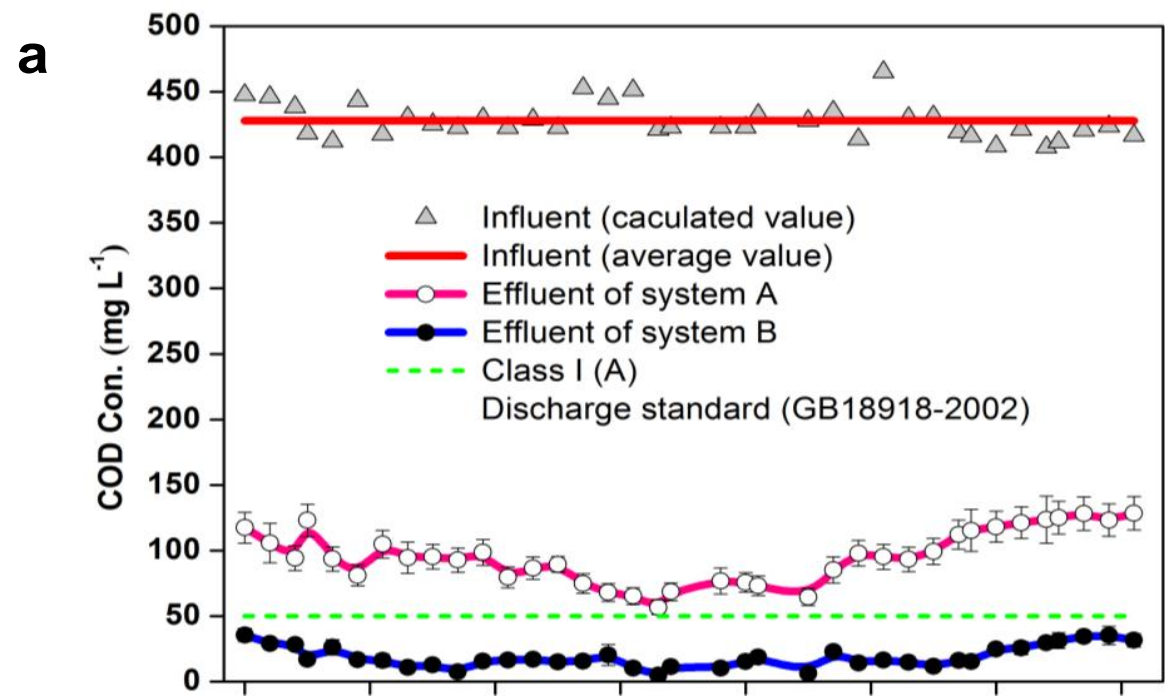

b

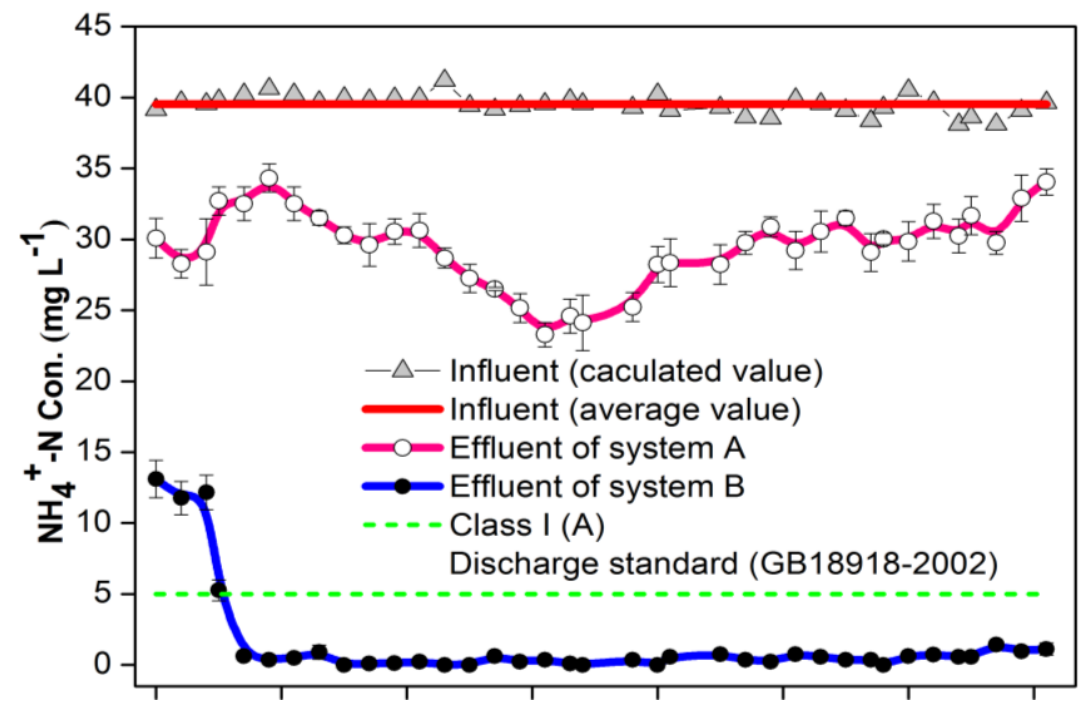

C

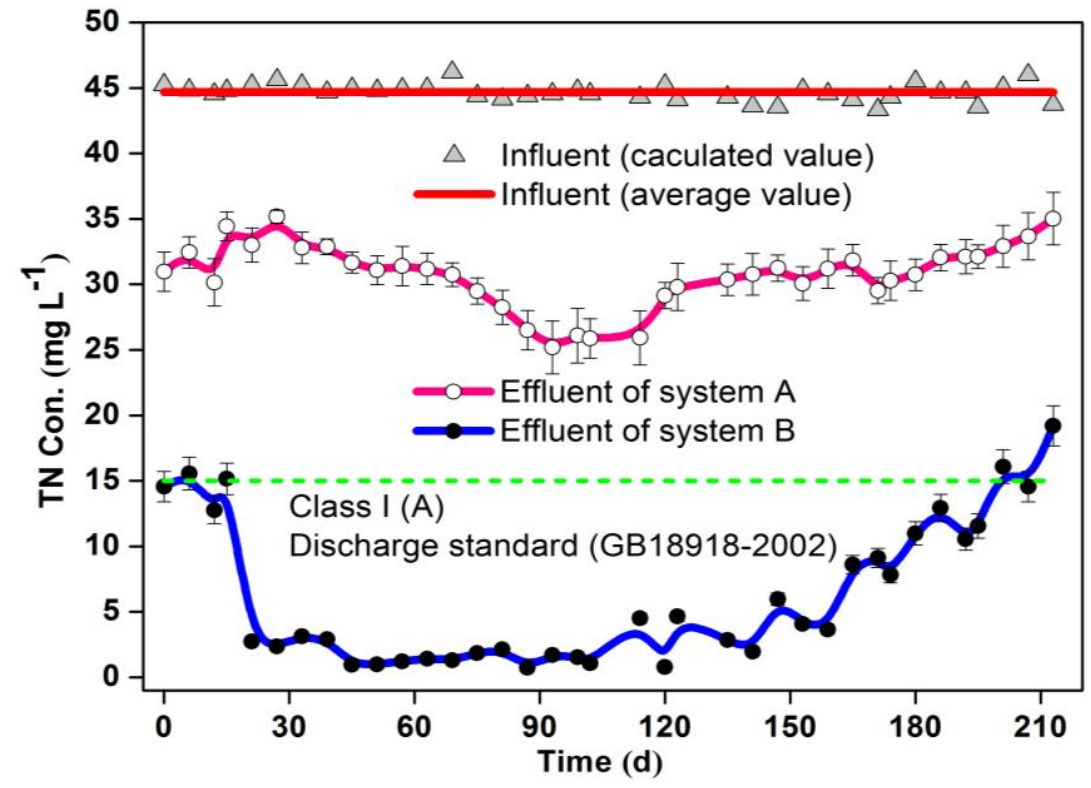

Figure 1 The influent and effluent water quality of the experimental SSF CWs without aeration and with intermittent aeration during 220 days of operation: (a) COD; (b) $\mathrm{NH}_{4}{ }^{+}-\mathrm{N}$ and (c) TN. 


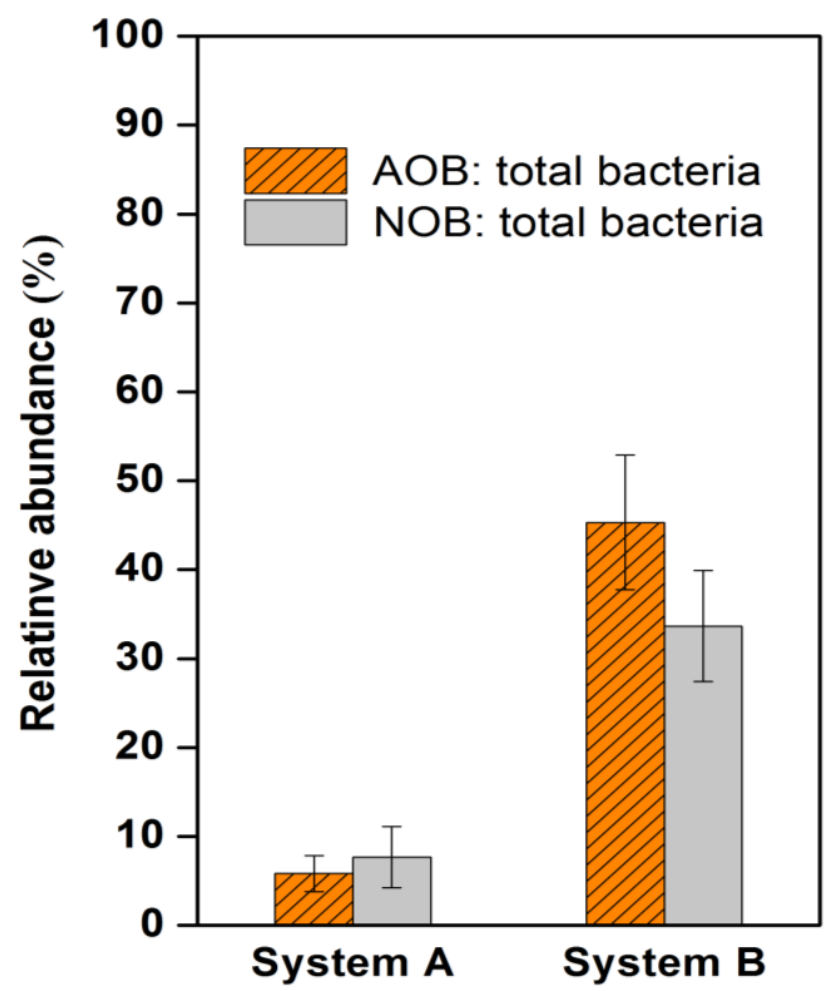

Figure 2 Relative abundance of $A O B$ and NOB in SSF CWs (A: without aeration, $\mathrm{B}$ : intermittent aeration) based on FISH analysis. 
Table 1 Comparative comparison of treatment performance of various enhancing strategies and techniques in CWs for wastewater treatment

\begin{tabular}{|c|c|c|c|c|c|c|}
\hline \multirow{2}{*}{ System } & \multirow{2}{*}{$\begin{array}{l}\text { Strategies and } \\
\text { techniques }\end{array}$} & \multirow{2}{*}{ Wastewater type } & \multicolumn{3}{|c|}{ Removal efficiency (\%) } & \multirow{2}{*}{ Reference } \\
\hline & & & COD & $\mathrm{NH}_{4}{ }^{+}-\mathrm{N}$ & TN & \\
\hline VF CW & intermittent aeration & Synthetic wastewater & 96 & 96 & 86 & This study \\
\hline VF CW & Continuous aeration & Synthetic wastewater & $90-94$ & $59-98$ & $69-92$ & $\begin{array}{l}\text { Ong et al. } \\
(2010)\end{array}$ \\
\hline VF CW & Tidal flow operation & Piggery wastewater & 82 & 58 & - & $\begin{array}{l}\text { Sun et al. } \\
(2006)\end{array}$ \\
\hline VF CW & Effluent recirculation & Domestic wastewater & 84 & 73 & 72 & $\begin{array}{l}\text { Foladori et al. } \\
\qquad(2013)\end{array}$ \\
\hline VF CW & Bioaugmentation & Raw sewage & 65 & 84 & 74 & $\begin{array}{l}\text { Zhao et al. } \\
\qquad(2016)\end{array}$ \\
\hline Integrated CW & $\begin{array}{c}\text { Microbial fuel cell -VF } \\
\text { CW }\end{array}$ & Synthetic wastewater & 100 & 91 & - & $\begin{array}{l}\text { Oon et al. } \\
(2015)\end{array}$ \\
\hline Integrated CW & Electrolysis- tidal CW & Synthetic wastewater & 85 & 80 & - & $\begin{array}{l}\text { Ju et al. } \\
\text { (2014) }\end{array}$ \\
\hline Integrated CW & $\begin{array}{c}\text { Biological reactor-VF } \\
\mathrm{CW}\end{array}$ & Domestic wastewater & 82 & - & 59 & $\begin{array}{l}\text { Bilgin et al. } \\
(2014)\end{array}$ \\
\hline
\end{tabular}




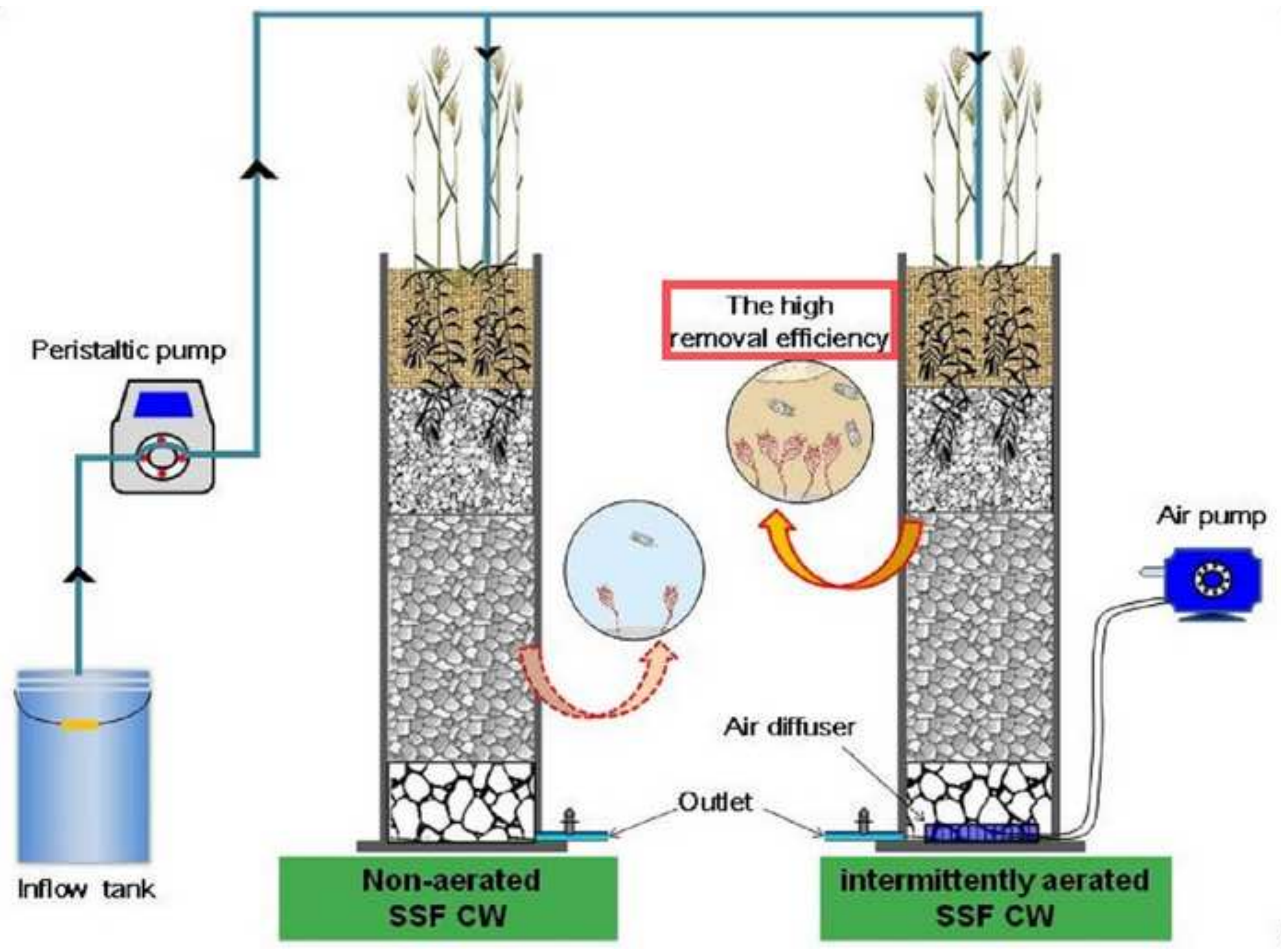

